\title{
PERLINDUNGAN HUKUM BAGI PEMILIK MEREK TERKENAL BERDASARKAN UNDANG-UNDANG NOMOR 20 TAHUN 2016 TENTANG MEREK DAN INDIKASI GEOGRAFIS
}

\author{
Indira Hastuti*
}

\begin{abstract}
Brand protection is not only given to local brands but also to well-known brands that already exist but have not been registered in Indonesia. Protection of well-known brands is given both preventive and repressive protection. Based on this, it is interesting to raise the issue of legal protection for well-known owners based on Law Number 20 of 2016 concerning Trademarks and Geographical Indications. Based on the discussion it can be concluded that Law Number 20 of 2016 concerning Trademarks and Geographical Indications provides legal protection to owners of well-known brands as stipulated in Article 21 paragraph (1), Article 76 paragraph (1) and Article 83.
\end{abstract}

Keywords: Legal Protection, Famous Brands, Geographical Indications

\section{PENDAHULUAN}

Tujuan utama adanya sistem Hak Kekayaan Intelektual adalah untuk menjamin agar proses kreatif tersebut terus berlangsung dengan menyediakan perlindungan hukum yang memadai dan menyediakan sanksi terhadap pihak yang menggunakan proses kreatif tersebut tanpa izin. .

Salah satu hak kekayaan intelektual yang dihasilkan oleh manusia adalah Merek. Menurut Pasal 1 butir 1 UndangUndang Nomor 20 tahun 2016 tentang Merek dan Indikasi Geografis, disebutkan bahwa Merek adalah tanda yang dapat ditampilkan secara grafis berupa gambar, logo, nama, kata, huruf, angka, susunan warna, dalam bentuk 2 (dua) dimensi dan/atau 3 (tiga) dimensi, suara, hologram, atau kombinasi dari 2 (dua) atau lebih unsur

* Indira Hastuti adalah Pengajar di Fakultas Hukum UNTAG Semarang, Bidang Kajian Hukum Perdata Email : indirahastuti@gmail. co.id

1 Suryo Utomo, 2010. Hak Kekayaan Intelektual (HKI) di Era Global: Sebuah Kajian Kontemporer. Yogyakarta: Graha Ilmu, hlm 2 tersebut untuk membedakan barang dan/atau jasa yang diproduksi oleh orang atau badan hukum dalam kegiatan perdagangan barang dan/atau jasa. Pemerintah sejak lama telah memberikan perhatian terhadap merek sebagai salah satu kekayaan intelektual yang harus dilindungi melalui perundangan -undangan yang terakhir dengan UndangUndang Nomor 20 tahun 2016 tentang merek dan Indikasi Geografis. Pemerintah dalam pertimbangannya menyatakan bahwa di dalam era perdagangan global, sejalan dengan konvensi internasional yang telah diratifikasi Indonesia, peranan Merek dan Indikasi Geografis menjadi sangat penting terutama dalam menjaga persaing an usaha yang sehat, berkeadilan, pelindungan konsumen, serta pelindungan Usaha Mikro, Kecil, dan Menengah dan industri dalam negeri.

Perlindungan terhadap merek tidak hanya diberikan kepada merek lokal tetapi juga kepada merek terkenal yang sudah ada namun belum terdaftar di Indonesia. Perlindungan terhadap merek terkenal diberikan baik perlindungan yang bersifat 
preventive maupun yang bersifat represif. Perlindungan yang preventitive terdapat dalam ketentuan Pasal 21 Undang-Undang Nomor 20 Tahun 2016 tentang Merek dan Indikasi Geografis, sedang perlindungan represifnya ada dalam pasal-pasal yang memuat ketentuan pidana, yaitu dari Pasal 100 sampai dengan Pasal 103 UndangUndang Nomor 20 Tahun 2016 tentang Merek dan Indikasi Geografis.

Negara berkewajiban dalam melakukan penegakan hukum terhadap merek dan indikasi geografis, jika terdapat pelanggaran atas merek terdaftar. Bagi pemilik merek dapat mengajukan gugatan ke Pengadilan Niaga sebagai diatur dalam ketentuan Pasal 76 ayat (3) UndangUndang Nomor 20 Tahun 2016 tentang Merek dan Indikasi Geografis yang menyatakan bahwa Gugatan pembatalan diajukan kepada Pengadilan Niaga terhadap pemilik Merek terdaftar.

Berdasarkan uraian di atas, menarik untuk mengangkat permasalahan mengenai perlindungan hukum bagi pemilik terkenal berdasarkan Undang-Undang Nomor 20 tahun 2016 tentang Merek dan Indikasi Geografis.

\section{Pembahasan}

\section{Tinjauan tentang Hak atas Kekayaan Intelektual}

Hak atas Kekayaan Intelektual (HaKI) pada dasarnya adalah padanan kata yang biasa digunakan untuk Intellectual Property Rights (IPR) atau Geistiges Eigentum, dalam bahasa Jermannya, ${ }^{2}$ yakni hak khusus yang bersifat eksklusif (khusus) yang dimiliki oleh para pencipta/penemu sebagai hasil aktivitas

2 Syafrinaldi, 2010, Hukum Tentang Perlindungan Hak Milik Intelektual Dalam Menghadapi Era Globalisasi,Jakarta : UIR Press, hlm 2 intelektual kreativitas yang bersifat khas dan baru. ${ }^{3}$ Secara sederhana Hak Kekayaan Intelektual merupakan hak untuk me nikmati secara ekonomis hasil dari suatu kreativitas intelektual.

Hak atas Kekayaan Intelektual ter diri dari tiga kata kunci, yaitu Hak, Kekaya an, dan Intelektual. Kekayaan merupakan abstraksi yang dapat dimiliki, dialihkan, dibeli, maupun dijual. ${ }^{4}$ Terminologi Hak atas Kekayaan Intelektual (HaKI) digunakan untuk pertama kalinya pada tahun 1790. Dikatakan oleh Fichte pada tahun 1793 bahwa hak milik dari si pencipta ada pada bukunya, yang dimaksud dengan hak milik di sini bukan buku sebagai benda, tetapi buku dalam pengertian isinya.

Hak atas Kekayaan Intelektual juga dikenal dengan istilah Hak Milik Intelektual. Hak milik pada dasarnya merupakan masalah pokok dalam dunia ekonomi, dari mana ia diperoleh dan bagaimana konsekuensinya yang muncul dari pemilikan tersebut. Hak milik atas sesuatu benda adalah satu fenomena yang senantiasa ada, hingga dipandang sebagai salah satu aspek kebutuhan esensial dalam hidup manusia. Umat manusia memandang bahwa memiliki sesuatu merupakan pembawaan naluriyah manusia, itu adalah hak alami, hak kodrati atau hak asasi manusia yang wajib dihormati dan dilindungi. ${ }^{6}$ Manusia memiliki naluri yang selalu ingin mengumpulkan harta yang lebih banyak dan enggan disaingi, misalnya selalu mempersoalkan masalah hak milik yang tidak berkesudahan, baik hak itu perindividu maupun perkelompok. ${ }^{7}$

3 Iswi Hariyani, 2010, Prosedur Mengurus HAKI (Hak atas kekayaan Intelektual) Yang Benar, Yogyakarta:Pustaka Yustisia, hlm 16

4 Agus Candra Suratmaja, 2010, Hak Kekayaan Intelektual,Jakarta: Pustaka Literasi, hlm 25

5 Syafrinaldi, Op.cit, hlm 13

6 Ahmad Azhar Basyir, 1978, Garis-Garis Besar Sistem Ekonomi Islam, Yogyakarta : UGM Yogyakarta, hlm 49

$7 \quad$ Ibid, hlm 52 
Menurut Abdul Kadir Muhammad. Hak atas Kekayaan Intelektual (HaKI) merupakan hasil dari intelektual manusia yang dijelmakan dalam suatu bentuk ciptaan atau penemuan. ${ }^{8}$ Kekayaan intelektual merupakan kekayaan atas segala hasil produksi kecerdasan daya pikir seperti teknologi, pengetahuan, seni, sastra, gubahan lagu, karya tulis, karikatur, dan lain-lain yang berguna untuk manusia.' Objek yang diatur dalam Hak Kekayaan Inteletual adalah karya-karya yang timbul atau lahir karena kemampuan intelektual manusia. ${ }^{10}$ Sistem Hak Kekayaan Intelektual merupakan hak privat (private rights). Seseorang bebas untuk mengajukan permohonan atau mendaftarkan karya intelektualnya atau tidak. Hak eksklusif yang diberikan Negara kepada individu pelaku Hak Kekayaan Intelektual (inventor, pencipta, pendesain dan sebagainya) tiada lain dimaksudkan sebagai penghargaan atas hasil karya (kreativitas) nya dan agar orang lain terangsang untuk dapat lebih lanjut mengembangkannya lagi, sehingga dengan sistem Hak Kekayaan Intelektual tersebut kepentingan masyarakat ditentukan melalui mekanisme pasar.

Sistem Hak atas Kekayaan Intelektual pada hakekatnya menunjang diadakannya sistem dokumentasi yang baik atas segala bentuk kreativitas manusia sehingga kemungkinan dihasilkannya teknologi atau karya lainnya yang sama dapat dihindari atau dicegah. Dengan dukungan dokumentasi yang baik tersebut, diharapkan masyarakat dapat memanfaat kannya dengan maksimal untuk keperluan hidupnya atau mengembangkannya lebih lanjut untuk memberikan nilai tambah yang lebih tinggi lagi. ${ }^{11}$

8 Abdulkadir Muhammad,2007, Kajian Hukum Ekonomi Hak Kekayaan Intelektual Bandung: Citra Aditya Bakti, hlm. 9

9 Sutedi, A,2009, Hak Atas Kekayaan Intelektual, Jakarta : . Sinar Grafika, hlm 38

10 Ditjend HKI, 2006, Buku Panduan Hak Kekayaan Intelektual, Jakarta : Ditjen HKI, hlm 7

11 ibid
Ruang lingkup Hak Kekayaan Intelektual, secara umum dapat digolongkan dalam dua kategori utama, yaitu : ${ }^{12}$

\section{a. Hak Cipta (Copyrights)}

Ruang lingkup hak cipta adalah karya cipta dalam bidang ilmu pengetahuan, seni, dan sastra

b. Hak Kekayaan Industri (Industrial Property Rights)

Ruang lingkup hak kekayaan industri adalah di bidang teknologi yang meliputi: ${ }^{13}$

1) Paten (Patent)

2) Desain Industri (Industrial Design)

3) Merek (Trademark)

4) Desain tata letak sirkuit terpadu (layout design of integrated circuit)

5) Rahasia dagang (Trade secret)

6) Perlindungan Varietas Tanaman (Plant Variety Protection)

Adanya penggolongan ruang lingkup Hak Kekayaan Intelektual ke dalam Hak Cipta dan Hak Kekayaan Industri diperlukan karena ada perbedaan sifat hasil ciptaan dan hasil temuan. Hal ini dikarenakan perlindungan terhadap hasil ciptaan bersifat otomatis oleh negara sejak saat pertama kali ciptaan tersebut muncul ke dunia nyata meskipun ciptaan tersebut belum dipublikasikan dan belum didaftarkan. Hal ini berbeda dengan Hak Kekayaan Industri yang ditentukan berdasarkan pihak pertama kali yang mendaftarkan hasil intelektualnya ke instannsi berwenang dan berhasil disetujui.

Hak atas Kekayaan Intelektual sebagai hak eksklusif bagi mereka yang mencipta atau menemukan pertama kali perlu diberikan perlindungan. Tujuan Perlindungan terhadap Hak atas kekayaan Intelektual pada hakekatnya antara lain adalah untuk ${ }^{14}$ :

a. Memberikan kepastian hukum kepada para pencipta dan/penemu terhadap

12 Iswi Hariyani, Op.cit, hlm 17

13 Ibid, hlm 18

$14 \mathrm{Ibid}, \mathrm{hlm} 25-26$ 
status hukum dari hasil ciptaan dan/atau hasil temuan

b. Menjamin rasa keadilan kepada para pencipta dan/atau penemu yang selama ini kurang mendapat perlindungan hukum atas hasil jerih payah mereka

c. Memberikan penghargaan setinggitinginya kepada para pencipta dan/atau penemu sehingga mereka tetap bergairah menghasilkan hal-hal yang baru dan khas

d. Mendorong tumbuhnya daya kreativitas di dalam masyarakat

e. Mendorong tumbuhnya sector ekonomi kreatif dan industri kreatif

f. Mendorong kemajuan bangsa dan peradaban manusia

g. Mendorong publikasi hasil ciptaan dan/atau hasil temuan agar dapat diakses oleh masyarakat luas. Mencegah kemungkinan terjadinya duplikasi dan peniruan karya intelektual

h. Memberikan kepastian dan perlindung an hukum kepada pihak-pihak yang ingin memanfaatkan hasil karya inteletual untuk keperluan bisnis dan sebagainya.

\section{Tinjauan tentang Merek terkenal}

Pengertian Merek menurut Pasal 1 Ayat (1) Undang-Undang Nomor 20 Tahun 2016 tentang Merek dan Indikasi Geografis, adalah tanda yang dapat ditampilkan secara grafis berupa gambar, logo, nama, kata, huruf, angka, susunan warna, dalam bentuk 2 (dua) dimensi dan/atau 3 (tiga) dimensi, suara, hologram, atau kombinasi dari 2 (dua) atau lebih unsur tersebut untuk membedakan barang dan/atau jasa yang diproduksi oleh orang atau badan hukum dalam kegiatan perdagangan barang dan/atau jasa.

Definisi merek terkenal sampai sekarang belum didapat satu kesepahaman yang dapat diterima secara umum. Ketentuan mengenai perlihdungan merek terkenal terdapat dalam Konvensi Paris yang telah diamandemen ketika dilakukan konferensi diplomatik mengenai amandemen dan revisi Konvensi Paris di Den Haag pada tahun 1925 dengan beberapa kali revisi.

Pasal 16 ayat (2) TRIPs tidak memberikan definisi mengenai merek terkenal, namun hanya berhasil membuat kriteria sifat keterkenalan suatu merek, yakni dengan memperhatikan faktor pengetahuan tentang merek di kalangan tertentu dalam masyarakat, termasuk pengetahuan negara peserta tentang kondisi merek yang bersangkutan, yang diperoleh dari hasll promosi merek tersebut. Ketentuan Pasal 12 ayat (2) TRIPs tersebut kemudian diadopsi oleh Penjelasan Pasal 21 ayat (1) Undang-Undang Nomor 20 Tahun 2016 tentang Merek dan lndikasi Geografis.

Undang-Undang Nomor 20 Tahun 2016 tentang Merek dan Indikasi Geografis tidak memberikan definisi mengenai merek terkenal. Merek terkenal mengandung makna "terkenal" menurut pengetahuan umum masyarakat. Merek terkenal yaitu merek yang dikenal luas oleh sektor-sektor relevan didalam masyarakat. Ada dua terminologi hukum yang memiliki pengertian sama dengan merek terkenal, yaitu "famous mark" dan "well known mark. ${ }^{15}$ Merek terkenal dalam bahasa asing disebut "well-known" yang diterjemahkan menjadi terkenal, begitu juga kata "famous" sehigga pengertian merek terkenal tidak membedakan arti atau tidak menentukan tingkatan arti "famous mark" dan "well known mark". Begitu juga putusan-putusan dalam kasus-kasus merek terkenal. Hakim senantiasa mengacu merek terkenal pada

15 Rahmi Jened, 2015, Hukum Merek dalam Era Global \& Integrasi Ekonomi, Jakarta: Prenadamedia Group, hlm. 241 
"well-known mark" yang mengaitkan pada Pasal 6 bis Konvensi Paris, namun Pasal 6bis Konvensi Paris sendiri tidak memberikan definisi atau kriteria tentang merek terkenal dan diserahkan sepenuhnya pada masing-masing negara. ${ }^{16}$

Undang-Undang Nomor 20 Tahun 2016 tentang Merek dan Indikasi Geografis meskipun tidak memberikan definisi atau pengertian mengenai merek terkenal, pemahaman tentang merek terkenal dapat ditelusuri dari penjelasan Pasal 21 ayat (1) huruf $b$ Undang-Undang Nomor 20 Tahun 2016 tentang Merek dan Indikasi Geografis yang menyatakan: Penolakan Permohonan yang mempunyai persamaan pada pokoknya atau keseluruhan dengan Merek terkenal milik pihak lain untuk barang dan/atau jasa yang sejenis dilakukan dengan memperhatikan pengetahuan umum masyarakat mengenai Merek tersebut di bidang usaha yang bersangkutan.

Di samping itu, diperhatikan pula reputasi Merek tersebut yang diperoleh karena promosi yang gencar dan besarbesaran, investasi di beberapa negara di dunia yang dilakukan oleh pemiliknya, dan disertai bukti pendaftaran Merek dimaksud dibeberapa negara.

Jika hal tersebut belum dianggap cukup, Pengadilan Niaga dapat memerintah kan lembaga yang bersifat mandiri untuk melakukan survei guna memperoleh kesimpulan mengenai terkenal atau tidaknya Merek yang menjadi dasar penolakan.

Berdasarkan penjelasan Pasal 21 di atas, dapat dipahami bahwa kriteria merek terkenal memiliki dua unsur penting, yaitu;

a. Pengetahuan umum masyarakat mengenai Merek tersebut di bidang usaha yang bersangkutan dan

16 Insan Budi Maulana, 1999, Perlindungan Merek Terkenal di Indonesia dari Masa ke Masa, Bandung: PT Citra Aditya Bakti,hlm. 22-23 b. Reputasi Merek tersebut yang diperoleh karena promosi yang gencar dan besar-besaran, investasi di beberapa negara di dunia yang dilakukan oleh pemiliknya, disertai bukti pendaftaran Merek dimaksud di beberapa negara.

Merek berdasarkan reputasi (reputation) dan kemashuran (renown) suatu merek, dapat dibedakan dalam tiga jenis, yaitu: ${ }^{17}$

a. Merek biasa (normal marks)

Merek biasa adalah merek yang tergolong tidak memiliki reputasi tinggi. Merek yang berderajat "biasa" ini dianggap kurang memberi pancaran simbolis gaya hidup baik dari segi pemakaian dan teknologi, masyarakat konsumen melihat merek tersebut kualitasnya rendah. Merek ini juga dianggap tidak memiliki drawing power yang mampu memberi sentuhan keakraban dan kekuatan mitos (mythical power) yang sugestif kepada masyarakat konsumen, dan tidak mampu membentuk lapisan pasar dan pemakai.

b. Merek terkenal (wellknown marks)

Di atas merek biasa terdapat merek terkenai, yakni merek yang memiliki reputasi tinggi. Merek yang demikian itu memiliki kekuatan pancaran yang memukau dan manarik, sehingga jenis barang apa saja yang berada di bawah merek itu langsung menimbulkan sentuhan keakraban (familiar attachement) dan ikatan mitos (mythical contexfj kepada segala lapis an konsumen.

c. Merek termashur (famous marks)

Tingkat derajat merek yang tertinggi adalah merek termashur. Sedemikian rupa mashumya di seluruh dunia,

17 M. Yahya Harahap. 1996. Tinjauan Merek Secara Umum dan Hukum Merek di Indonesia Berdasarkan Undang-UndangNomor 19 Tahun 1992, Jakarta: Rineka Cipta hlm, 80-81 
mengakibatkan reputasinya digolong kan sebaqai "merek aristokrat dunia". Dalarn kenyataannya sangatlah sulit membedakan antara merek terkenal dan merek termashur.

\section{Perlindungan Hukum Bagi Pemilik Terkenal Berdasarkan Undang- Undang Nomor 20 Tahun 2016 Tentang Merek Dan Indikasi Geografis}

Masalah perlindungan hukum bagi pemilik merek terkenal merupakan satu hal yang sangat menjadi perhatian para Hakim di Indonesia. Hal ini berkaitan erat dengan masalah hubungan internasional dan nama baik Indonesia di mata dunia internasional. Selama ini hukum di Indonesia dianggap paling lemah di antara negara-negara asia tenggara, sehingga dunia internasional selalu menyoroti setiap keputusan yang dihasilkan oleh para penegak hukum Indonesia. Masalah Hak Kekayaan Intelektual (HKI) termasuk salah satu masalah yang disoroti dalam dasa warsa terakhir, terutama menyangkut kepentingan dunia usaha yang semakin mengglobal. Oleh karena itu tidak berlebihan apabila banyak keputusan Mahkamah Agung yang menyangkut persoalan merek memberikan keputusan yang menguntungkan pemilik merek terkenal yang notabene lebih banyak berasal dari luar negeri.

Secara normatif Undang-Undang Nomor 20 Tahun 2016 tentang Merek dan Indikasi Geografis menganut sistem konsitutif atau "first to file principle", yakni adanya kepastian hukum bagi pemilik merek yang telah terdaftar pertama kali. Berdasarkan prinsip tersebut.Pemiilik merek yang terdaftar pertama kali dianggap sebagai pemilik merek yang sah, sehingga keberadaanya tidak dapat diganggu gugat. Dalam kenyataannya prinsip tersebut tidak dapat di berlakukan secara mutlak hal tersebut dapat dilihat dari berbagai kasus gugatan pembatalan terhadap merek terdaftar yang di ajukan ke Pengadilan dan dimenangkan oleh Penggugat. Pengadilan dapat melakukan pembatalan terhadap merek yang telah terdaftar berdasarkan Pasal 76 Undang-Undang Nomor 20 tahun 2016 tentang Merek dan Indikasi Geografis yang menyatakan:

a. Gugatan pembatalan Merek terdaftar dapat diajukan oleh pihak yang berkepentingan berdasarkan alasan sebagaimana dimaksud dalam Pasal 20 dan/atau Pasal 21.

b. Pemilik Merek yang tidak terdaftar dapat mengajukan gugatan sebagai mana dimaksud pada ayat (1) setelah mengajukan Permohonan kepada Menteri.

c. Gugatan pembatalan diajukan kepada Pengadilan Niaga terhadap pemilik Merek terdaftar.

Berdasarkan ketentuan Pasal 76 ayat (1) Undang-Undang Nomor 20 tahun 2016 tentang Merek dan Indikasi Geografis, gugatan didasarkan pada alasan sebagaiumana dimaksud Pasal 20 dan Pasal 21.

Pasal 20 Undang-Undang Nomor 20 tahun 2016 tentang Merek dan Indikasi Geografis menyatakan: Merek tidak dapat didaftar jika :

a. Bertentangan dengan ideologi negara, peraturan perundang-undangan, moralitas, agama, kesusilaan, atau ketertiban umum;

b. Sama dengan, berkaitan dengan, atau hanya menyebut barang dan/atau jasa yang dimohonkan pendaftarannya;

c. Memuat unsur yang dapat menyesat kan masyarakat tentang asal, kualitas, jenis, ukuran, macam, tujuan peng gunaan barang dan/atau jasa yang dimohonkan pendaftarannya atau merupakan nama varietas tanaman yang dilindungi untuk barang dan/atau 
jasa yang sejenis;

d. Memuat keterangan yang tidak sesuai dengan kualitas, manfaat, atau khasiat dari barang dan / atau jasa yang diproduksi

e. Tidak memiliki daya pembeda; dan/ atau

f. Merupakan nama umum dan/atau lambang milik umum.

Pasal 21 Undang-Undang Nomor 20 tahun 2016 tentang Merek dan Indikasi Geografis menegaskan:

Permohonan ditolak jika Merek tersebut mempunyai persamaan pada pokoknya atau keseluruhannya dengan:

a. Merek terdaftar milik pihak lain atau dimohonkan lebih dahulu oleh pihak lain untuk barang dan/atau jasa sejenis;

b. Merek terkenal milik pihak lain untuk barang dan/atau jasa sejenis;

c. Merek terkenal milik pihak lain untuk barang dan/atau jasa tidak sejenis yang memenuhi persyaratan tertentu; atau

d. Indikasi Geografis terdaftar. tersebut:

Permohonan ditolak jika Merek

a. Merupakan atau menyerupai nama atau singkatan nama orang terkenal, foto, atau nama badan hukum yang dimiliki orang lain, kecuali atas persetujuan tertulis dari yang berhak;

b. Merupakan tiruan atau menyerupai nama atau singkatan nama, bendera, lambang atau simbol atau emblem suatu negara, atau lembaga nasional maupun internasional, kecuali atas persetujuan tertulis dari pihak yang berwenang; atau

c. Merupakan tiruan atau menyerupai tanda atau cap atau stempel resmi yang digunakan oleh negara atau lembaga Pemerintah, kecuali atas persetujuan tertulis dari pihak yang berwenang.

Permohonan ditolak jika diajukan oleh Pemohon yang beriktikad tidak baik. Ketentuan lebih lanjut mengenai penolakan
Permohonan Merek sebagaimana dimaksud pada ayat (1) huruf a sampai dengan huruf $\mathrm{c}$ diatur dengan Peraturan Menteri

Dijelaskan dalam penjelasan Pasal 21 ayat (1) Undang-Undang Nomor 20 tahun 2016 tentang Merek dan Indikasi Geografis bahwa yang dimaksud dengan "persamaan pada pokoknya" adalah kemiripan yang disebabkan oleh adanya unsur yang dominan antara Merek yang satu dengan Merek yang lain sehingga menimbulkan kesan adanya persamaan, baik mengenai bentuk, cara penempatan, cara penulisan atau kombinasi antara unsur, maupun persamaan bunyi ucapan, yang terdapat dalam Merek tersebut. Adapun yang dimaksud dengan "Merek yang dimohonkan lebih dahulu" adalah Permohonan pendaftaran Merek yang sudah disetujui untuk didaftar.

Menurut penjelasan Pasal 21 ayat (1) Undang-Undang Nomor 20 tahun 2016 tentang Merek dan Indikasi Geografis, Penolakan Permohonan yang mempunyai persamaan pada pokoknya atau keseluruhan dengan Merek terkenal milik pihak lain untuk barang dan/atau jasa yang sejenis dilakukan dengan memperhatikan pengetahuan umum masyarakat mengenai Merek tersebut di bidang usaha yang bersangkutan. Di samping itu, diperhatikan pula reputasi Merek tersebut yang diperoleh karena promosi yang gencar dan besar-besaran, investasi di beberapa negara di dunia yang dilakukan oleh pemiliknya, dan disertai bukti pendaftaran Merek dimaksud di beberapa negara. Jika hal tersebut belum dianggap cukup, Pengadilan Niaga dapat memerintahkan lembaga yang bersifat mandiri untuk melakukan survei guna memperoleh kesimpulan mengenai terkenal atau tidaknya Merek yang menjadi dasar penolakan.

Menurut penjelasan Pasal 76 ayat (1) Undang-Undang Nomor 20 tahun 2016 
tentang Merek dan Indikasi Geografis, yang dimaksud dengan "pihak yang berkepentingan" antara lain pemilik Merek terdaftar, jaksa, yayasan/ lembaga di bidang konsumen, dan majelis/lembaga keagamaan.

Selanjutnya dalam penjelasan Pasal 76 ayat (2) Undang-Undang Nomor 20 tahun 2016 tentang Merek dan Indikasi Geografis disebutkan bahwa yang dimaksud dengan "pemilik Merek yang tidak terdaftar" antara lain pemilik Merek yang iktikad baik tetapi tidak terdaftar atau pemilik Merek terkenal tetapi Mereknya tidak terdaftar.

Bagi pemilik merek terdaftar dan/atau penerima lisensi merek terdaftar, menurut ketentuan Pasal 83 ayat (1) Undang-Undang Nomor 20 tahun 2016 tentang Merek dan Indikasi Geografis, dapat mengajukan gugatan terhadap pihak lain yang secara tanpa hak menggunakan Merek yang mempunyai persamaan pada pokoknya atau keseluruhannya untuk barang dan/atau jasa yang sejenis berupa:

a. Gugatan ganti dan/atau

b. Penghentian semua perbuatan yang berkaitan dengan penggunaan Merek tersebut.

Selanjutnya menurut ketentuan Pasal 83 ayat (2) Undang-Undang Nomor 20 tahun 2016 tentang Merek dan Indikasi Geografis, Gugatan sebagaimana dimaksud pada ayat (1) dapat pula diajukan oleh pemilik Merek terkenal berdasarkan putusan pengadilan. Gugayan diajukan ke pengadilan niaga. Hal ini ditegaskan dalam ketentuan Pasal 83 ayat (3) UndangUndang Nomor 20 tahun 2016 tentang Merek dan Indikasi Geografis, yang menyatakan bahwa Gugatan sebagaimana dimaksud pada ayat (1) diajukan kepada Pengadilan Niaga.

Berkaitan dengan penegakan hukum pidana, Undang-Undang Nomor 20 tahun 2016 tentang Merek dan Indikasi
Geografis, mengatur dalam Bab XVIII Ketentuan Pidana mulai Pasal 100 hingga Pasal 103 sebagai berikut:

\section{Pasal 100}

a. Setiap Orang yang dengan tanpa hak menggunakan Merek yang sama pada keseluruhannya dengan Merek terdaftar milik pihak lain untuk barang dan/atau jasa sejenis yang diproduksi dan/atau diperdagangkan, dipidana dengan pidana penjara paling lama 5 (lima) tahun dan/atau pidana denda paling banyak $\mathrm{Rp} 2.000 .000 .000,00$ (dua miliar rupiah).

b. Setiap Orang yang dengan tanpa hak menggunakan Merek yang mem punyai persamaan pada pokoknya dengan Merek terdaftar milik pihak lain untuk barang dan/atau jasa sejenis yang diproduksi dan/atau diperdagang kan, dipidana dengan pidana penjara paling lama 4 (empat) tahun dan/atau denda paling banyak Rp 2.000.000.000,00 (dua miliar rupiah).

c. Setiap Orang yang melanggar ketentuan sebagaimana dimaksud pada ayat (1) dan ayat (2), yang jenis barangnya mengakibatkan gangguan kesehatan, gangguan lingkungan hidup, dan/atau kematian manusia, dipidana dengan pidana penjara paling lama 10 (sepuluh) tahun dan/atau denda paling banyak Rp 5.000.000.000,00 (lima miliar rupiah).

\section{Pasal 101}

a. Setiap Orang yang dengan tanpa hak menggunakan tanda yang mempunyai persamaan pada keseluruhan dengan Indikasi Geografis milik pihak lain untuk barang dan/atau produk yang sama atau sejenis dengan barang dan/atau produk yang terdaftar, 
dipidana dengan pidana penjara paling lama 4 (empat) tahun dan/atau denda paling banyak $\mathrm{Rp} 2.000 .000 .000,00$ (dua miliar rupiah).

b. Setiap Orang yang dengan tanpa hak menggunakan tanda yang mempunyai persamaan pada pokoknya dengan Indikasi Geografis milik pihak lain untuk barang dan/atau produk yang sama atau sejenis dengan barang dan/atau produk yang terdaftar, dipidana dengan pidana penjara paling lama 4 (empat) tahun dan/atau denda paling banyak $\mathrm{Rp} 2.000 .000 .000,00$ (dua miliar rupiah)

\section{Pasal 102}

Setiap Orang yang memperdagangkan barang dan/atau jasa dan/atau produk yang diketahui atau patut diduga mengetahui bahwa barang dan/atau jasa dan/atau produk tersebut merupakan hasil tindak pidana sebagaimana dimaksud dalam Pasal 100 dan Pasal 101 dipidana dengan pidana kurungan paling lama 1 (satu) tahun atau denda paling banyak Rp200.000.000,00 (dua ratus juta rupiah).

\section{Pasal 103}

Tindak pidana sebagaimana dimaksud dalam Pasal 100 sampai dengan Pasal 102 merupakan delik aduan.

Dalam praktek selama ini sistem konstitutif tersebut belum dilaksanakan secara murni atau tidak konsisten, padahal Undang-Undang Nomor 20 tahun 2016 tentang Merek dan Indikasi Geografis sebagai lembaga pengaturan di bidang merek harus mampu memberikan kepastian hukum atas karya intelektual (merek) dengan cara mendaftarkan hak atas merek sesuai prosedur yang di tetapkan secara normatif dalam Undang-Undang Nomor 20 tahun 2016 tentang Merek dan Indikasi Geografis. Dengan demikian pada pihakpihak yang melanggar hak-haknya dapt di tuntut. Tanpa pendaftaran tidak ada hak atas merek, juga tidak ada perlindungan. Sekali suatu merek didaftarkan dan memperoleh sertipikat merek maka ia akan dilindungi dan orang lain tidak dapat memakai merek yang sama. ${ }^{18}$

Menurut pandangan Gustav Radbruch, Undang-Undang di tuntut untuk dapat memberikan kepastian hukum. Peraturan perundang-undangan merupakan unsur utama untuk menciptakan kepastian hukum. ${ }^{19}$ Keharusan pendaftaran merek untuk mendapatkan hak atas merek sebagaimana diatur dalam undang-undang merek belum bisa menjamin kepastian hukum. Pendapat Algra dan Duvvendijk yang mengatakan bahwa perundangundangan memberikan kepastian mengenai nilai-nilai yang dipertaruhkan ${ }^{20}$ pada kenyataanya belum bisa di tetapkan dalam peraturan di bidang merek khusunya yang mengatur mengenai perolehan hak atas merek.

Jika ditelusuri lebih jauh bahwa hakikat sosial perundang-undangan adalah memiliki kekuasaan yang besar karena dibuat oleh kekuasaan tertinggi. ${ }^{21}$

. Undang-undang Merek yang menganut sistem konstitutif semestinya dapat melaksanakan ketentuan first to file principle secara konsisten. Pada kenyataannya sistem / prinsip tersebut tidak dapat diberlakukan secara konsisten terhadap merek-merek terkenal. Oleh karena itu perolehan hak atas merek dapat dikatakan menggunakan sistem konstitutif

\footnotetext{
18 Sudargo Gautama dan Rizawanto Winata, 1994 , komentar Undang-Undang Merek baru 1992 dan Peraturan-Peraturan Pelaksanaannya, Alumni; Bandung, hlm 5

19 Satjito Rahardjo, 2008, Ilmu Hukum, Alumni ; Bandung, hlm 21

20 Ibid, hlm 115

21 Ibid, hlm 116
} 
cenderung deklaratif, artinya selain memberlakukan first to use principle terhadap merek-merek terkenal. Kenyataan tersebut disebabkan adanya faktor yuridis dan faktor ekonomi sebagai berikut :

a. Faktor yuridis

Indonesia telah meratifikasi konvensi

Paris berdasarkan Keputusan Presiden Nomor 15 tahun 1997. Hal tersebut memberikan konsekuensi logis bagi Indonesia untuk memberlakukan ketentuan-ketentuan yang bersifat substansif yang menjadi dasar bagi pengaturan dalam peraturan perundang - undangan di bidang merek. Dalam konvensi Paris sendiri terdapat prinsip asimilasi yang menyatakan setiap warga negara anggota persatuan harus di perlakukan sama dengan warga negara yang berasal dari anggota persatuan. Demikian pula halnya dalam perjanjian TrlPs yang telah diartifikasi melalui Undang-Undang Nomor 7 Tahun 1994, terdapat prinsip National Treatmenty yang berisi sama dengan prinsip asimilasi

b. Faktor ekonomi

Faktor ekonomi ditunjukkan dengan adanya globalisasi yang menyebabkan adanya perkembangan internasional di bidang perdagangan sehingga membentuk pasar bebas, di mana produk-produk barang yang diperdagangkan banyak mengandung merek terkenal sehingga perlu mendapat perlindungan secara internasional. Peniruan merek terkenal yang dibiarkan dan bahkan dilegalisasi akan mendatangkan pembalasan pada sektor ekspor barang-barang ekspor tertentu. Pembalasan tersebut berupa hambatan perdagangan barang-barang lainnya maupun tindakan lainnya seperti penyiataan.
Berdasarkan kenyataan tersebut, perlindungan hukum bagi pemilik merek terkenal berdasarkan Undang-Undang Nomor 20 tahun 2016 tentang Merek dan Indikasi Geografis dapat diberikan terhadap pemilik merek terkenal meskipun belum terdaftar di Indonesia. Agar tetap memenuhi konsistensi dalam menganut sistem konstitutif, maka pemilik merek terkenal yang akan mengajukan gugatan nya ke Pengadilan harus mengajukan permohonan pendaftaran merek terlebih dahulu ke Direktorat Jenderal Cipta, Paten dan Merek. Dengan demikian pengajuan pembatalan merek terdaftar tetap didasarkan pada pemakaian merek yang memiliki persamaan pada pokoknya maupun persamaan secara keseluruhan.

\section{Kesimpulan}

Berdasarkan uraian di atas dapat disimpulkan bahwa Undang-Undang Nomor 20 tahun 2016 tentang Merek dan Indikasi Geografis memberikan perlindung an hukum kepada pemilik merek terkenal sebagaimana diatur dalam Pasal 21 ayat (1), Pasal 76 ayat (1) dan Pasal 83.

\section{Saran}

Pemerintah perlu melaksanakan perlindungan hukum terhadap pemilik merek terkenal secara optimal dalam rangka menjaga iklim usaha yang kondusif untuk menunjang perekonomian nasional.

\section{DAFTAR PUSTAKA}

Abdulkadir Muhammad,2007, Kajian Hukum Ekonomi Hak Kekayaan Intelektual Bandung: Citra Aditya Bakti

Agus Candra Suratmaja, 2010, Hak Kekayaan Intelektual, Jakarta : Pustaka Literasi 
Ahmad Azhar Basyir, 1978, Garis-Garis Besar Sistem Ekonomi Islam, Yogyakarta: UGM Yogyakarta

Ditjend HKI, 2006, Buku Panduan Hak Kekayaan Intelektual, Jakarta: Ditjen HKI

Insan Budi Maulana, 1999, Perlindungan Merek Terkenal di Indonesia dari Masa ke Masa, Bandung: PT Citra Aditya Bakti

Iswi Hariyani, 2010, Prosedur Mengurus HAKI (Hak atas kekayaan Intelektual) Yang Benar, Yogyakarta: Pustaka Yustisia,

M. Yahya Harahap. 1996. Tinjauan Merek Secara Umum dan Hukum Merek di Indonesia Berdasarkan UndangUndangNomor 19 Tahun 1992, Rineka Cipta: Jakarta

Rahmi Jened, 2015, Hukum Merek dalam Era Global \& Integrasi Ekonomi, Jakarta: Prenadamedia Group
Satjito Rahardjo, 2008, Ilmu Hukum, Alumni: Bandung

Sudargo Gautama dan Rizawanto Winata, 1994, komentar Undang-Undang Merek baru 1992 dan PeraturanPeraturan Pelaksanaannya, Alumni ; Bandung

Suryo Utomo, 2010. Hak Kekayaan Intelektual (HKI) di Era Global: Sebuah Kajian Kontemporer. Yogyakarta:Graha Ilmu

Sutedi, A,2009, Hak Atas Kekayaan Intelektual, Jakarta : . Sinar Grafika

Syafrinaldi, 2010, Hukum Tentang Perlindungan Hak Milik Intelektual Dalam Menghadapi Era Globalisasi, Jakarta : UIR Press

Undang-Undang Nomor 20 tahun 2016 tentang Merek dan Indikasi Geografis 